\title{
XXVII. Abstract of Dr. Hermann Kopp's researches on the specific weight of chemical compounds
}

\section{Henry Croft Esq.}

To cite this article: Henry Croft Esq. (1842) XXVII. Abstract of Dr. Hermann Kopp's researches on the specific weight of chemical compounds, Philosophical Magazine Series 3, 20:130, 177-187, DOI: $10.1080 / 14786444208650551$

To link to this article: http://dx.doi.org/10.1080/14786444208650551

册 Published online: 01 Jun 2009.

Submit your article to this journal $\lceil\pi$

Џ Article views: 3

Q View related articles $₫$ 
LONDON, EDINBURGH AND DUBLIN

PHILOSOPH ICAL MAGAZINE.

A N D

JOURNAL OF SCIENCE.

[THIRD SERIES.]

$M A R C H \quad 184.2$.

XXVII. Abstract of Dr. Hermann Kopp's Researches on the Specific Weight of Chemical Compounds*. By Henry Crofr, Esq., Teacher of Chemistry †.

CHEMISTS have lately commenced directing considerable attention to the "atomic volumes" of bodies, that is to say, the space occupied by an atom of any body, or, in other words, the quotient of the density into the atomic weight. In one of the preceding volumes of this Journal, Dr. Kopp has shown that perfectly isomorphous bodies possess the same atomic volume, and that in the cases of those bodies which are not perfectly isomorphous, every difference in the crystalline form is expressed by a difference in the atomic volume. The same author has lately published a work, entitled "Uber das specifische Gewicht der Chemischen Verbindungen," in which he discusses the composition of chemical bodies according to the volumes of their elements. The following is a short abstract of this work, which it seems very desirable to make known to English chemists. Dr. Kopp has struck out an entirely new branch in molecular chemistry, which promises to be hereafter of very great importance. The first attempt to determine the composition of bodies according to the volumes of their elements was made by Schröder (Poggendorff's Annals, 50, p. 553), but many objections may be raised to the manner in which this attempt was made, and to the conclusions therein deduced; a critique, by Dr. Kopp, of this work appeared in the 52nd volume of the same Journal. In his researches on the same subject, Dr. Kopp has en-

* Uber das Specifische Gewicht der Chemischen Verbindungen. Frankfurt, 1841 .

+ Communicated by the Author. Dr. Kopp's paper on the atomic volume and crystalline condition of bodies will be found in Phil. Mag. Third Series, vol. xviii. p. 255.

Phil. Mag. S. 3. Vol. 20. No. 130. March 184.2. 


\section{Mr. H. Croft's Abstract of Dr. H. Kopp's Rescarches}

deavoured to avoid those faults which he blamed in Schröder's work, and which consist principally therein, that Schröder made too great a number of arbitrary assumptions and suppositions, and, notwithstanding, considered the results of his theory as absolutely certain, forgetting that the probability of a theory becomes the less in proportion as the number of assumptions on which it is founded becomes greater. Dr. Kopp, on the contrary, believes that on this subject no absolutely true theory can at present be made, but still a very probable one may be proposed, whose probability is proved by its explaining, by means of the fewest possible assumptions, the greatest possible number of experimental facts. The views of Dr. Kopp, which are explained in the following paper, differ considerably from those of Schröder; but they embrace a much greater number of compounds, which they fully explain with very few assumptions.

It will be better first of all to give a tabular view of the atomic volumes of the simple bodies as obtained by dividing the atomic weights by the densities. 'These atomic volumes of simple bodies in an isolated state are called by Dr. Kopp the "Primitive atomic volume," to distinguish them from those which elements possess when they enter into combination; for in compounds they may be contained with atomic volumes quite different from their primitive ones. We will here give the atomic volumes as adopted by Dr. Kopp; the atomic weights (which are always those of Berzelius, with the exception of that of bismuth, which is taken as 1330 according to the latest researches) may be left out, as well as the observed densities, which agree very well with those calculated from the adopted atomic volumes. Cyanogen has been added.

TABLE I.-Primitive atomic volumes of the simple bodies, and of their calculated densities.

\begin{tabular}{|c|c|c|c|c|c|}
\hline & $\begin{array}{l}\text { Prim. } \\
\text { At. Vol, }\end{array}$ & $\begin{array}{l}\text { Caleul. } \\
\text { Density. }\end{array}$ & & \begin{tabular}{|} 
Prim. \\
At. Vol.
\end{tabular} & $\begin{array}{l}\text { Calcul. } \\
\text { Density }\end{array}$ \\
\hline Antimony & 120 & 6.72 & Iodine & 160 & $4 \cdot 93$ \\
\hline Arsenic & 80 & $5 \cdot 87$ & Iridium & 57 & $21 \cdot 6$ \\
\hline Bismuth & 135 & $9 \cdot 85$ & Lead. & 114 & $11 \cdot 35$ \\
\hline Bromine & 160 & $3 \cdot 06$ & Manganese & 44 & $7 \cdot 86$ \\
\hline Cadminm.. & 81 & $8 \cdot 60$ & Mercury .. & 93 & 13.6 \\
\hline Charcoal ... & 36 & $2 \cdot 11$ & Molybdenum .... & 69 & $8 \cdot 68$ \\
\hline Chlorine ... & 160 & $1 \cdot 38$ & Nickel . & 44 & $8 \cdot 41$ \\
\hline Chromium ...... & 69 & $5 \cdot 10$ & Osmitum $\ldots$ & 57 & $21 \cdot 8$ \\
\hline Cobalt ..... & 44 & $8 \cdot 39$ & Palladium & 57 & $11 \cdot 7$ \\
\hline Copper. & 44 & 900 & Phosphorus. & 111 & 1.77 \\
\hline Cyanogen.. & 160 & $1 \cdot 03$ & Platinum ... & 57 & $21 \cdot 6^{\circ}$ \\
\hline Gold ... & 65 & $19 \cdot 1$ & Potassium & 583 & $0 \cdot 84$ \\
\hline
\end{tabular}


Table (continued).

\begin{tabular}{|c|c|c|c|c|c|}
\hline & $\begin{array}{c}\text { Prim. } \\
\text { At. Vol. }\end{array}$ & $\begin{array}{l}\text { Calcul. } \\
\text { Density. }\end{array}$ & & \begin{tabular}{|l} 
Prim. \\
At. Vol.
\end{tabular} & \begin{tabular}{|l} 
Calcul. \\
Density
\end{tabular} \\
\hline Rhodiun & 57 & $11 \cdot 4$ & & 101 & $7 \cdot 28$ \\
\hline \begin{tabular}{|l} 
Selenium \\
Silver ...
\end{tabular} & 115 & $4 \cdot 30$ & Titanium ... & $\begin{array}{l}57 \\
69\end{array}$ & $5 \cdot 33$ \\
\hline Sodium... & $\begin{array}{l}1090 \\
292\end{array}$ & $\begin{array}{r}104 \\
0.99\end{array}$ & $\begin{array}{l}\text { Wouramium } \\
\text { Zinc.......... }\end{array}$ & $\begin{array}{l}69 \\
58\end{array}$ & 695 \\
\hline Sulphur & I01 & 1.99 & & & \\
\hline
\end{tabular}

From this table we see that the bodies contained in the several groups following possess equal atomic volumes.

Bromine, chlorine, iodine, cyanogen, chromium, molybdenum, wolframium, iron, cobalt, copper, manganese, nickel, iridium, osmium, pailadium, platinum, rhodium.

The atomic volume of silver is double that of gold.

$\begin{array}{lllll} & . . & \ldots & \text { potassium } \quad \ldots & \text { sodium. }\end{array}$

The atomic volume of a chemical compound is hardly ever equal to the sum of the prinitive atomic volumes of its elements. For instance, the atomic volume of chlorine $=160$, that of sulphur $=101$; but the atomic volume of the compound $\mathrm{S} \mathrm{Cl}$ is not $=160+101=261$, but according to observation it is $=225$. Consequently, in this compound either both or one of the elements have different atomic volumes from their primitive ones.

Only such compounds will be examined as we can consider as binary.

If the atomic volume of a compound is greater than the primitive atomic volumes of either of its components, we cannot tell whether one or both of the elements are contained in it with an atomic volume different from their primitive one; but we know for certain that one element in a compound does not possess its primitive atomic volume if the atomic volume of the compound is smaller than the primitive atomic volume of that element. It is not as yet possible to state for every compound, which element énters into it with its primitive atomic volume, or whether both acquire different ones. It is only possible to state this with a great degree of probability for such classes of compounds as have an analogous composition, so that in all the compounds there is one common element.

Schröder has found, namely, that if we have a series of analogous bodies, $\mathrm{A} \mathrm{O}, \mathrm{BO}, \mathrm{CO}$, whose atomic volumes we know, and if we know also the primitive atomic volumes of $\mathrm{A}, \mathrm{B}, \mathrm{C}$, we shall always obtain the same remainder if from the atomic volume of $\dot{A} \mathrm{O}$ we subtract the primitive atonic volume of $\mathrm{A}$, from the atomic volume of $\mathrm{BO}$, the primitive 
volume of $\mathrm{B}$, and from the atomic volume of $\mathrm{C} \mathrm{O}$ that of $\mathrm{C}$. For instance, in the case of the oxides:-

The atomic volume of $\mathrm{PbO}=146, \mathrm{Cd} \mathrm{O}=113, \mathrm{ZnO}=90$

Or for the nitrates :-

$$
\mathrm{Pb}=\frac{114, \mathrm{Cd}}{32}=\frac{81, \mathrm{Zn}}{32}=\frac{58}{32}
$$

$$
\begin{aligned}
& \text { Atomic volume of } \mathrm{Pb} \mathrm{N} \mathrm{N}^{2}=472, \mathrm{Ag} \mathrm{\textrm {N } ^ { 2 }} \mathrm{O}^{6}=488 \\
& \cdots \quad \ldots \quad \ldots \quad \mathrm{Pb}=\frac{114}{358}, \mathrm{Ag} \quad=\frac{130}{358}
\end{aligned}
$$

For the explanation of the atomic volumes of these bodies, we see that one assumption as to the atomic volume of one element is quite sufficient. We assume that the metal is contained therein with its primitive atomic volume. In the nitrates we say that the radical $\mathrm{N}^{2} \mathrm{O}^{6}$ has the atomic volume 358.

Dr. Kopp examines first the salts, and divides them into two groups, - salts of heavy metals and salts of light metals. He considers them according to the hydracid theory.

In the salts of heavy metals he assumes that the metal possesses its primitive atomic volume; but with the salts of the light metals this is not possible, for the atomic volumes of the salts are often smaller than the primitive atomic volumes of the component metals.

He therefore assumes for the light metals a peculiar atomic

\begin{tabular}{|c|c|c|c|}
\hline Ammoniunı ...... & 218 & Magnesium ....... & \\
\hline Barium.............. & 14.3 & Sodium.............. & 130 \\
\hline Calcium ........ & 60 & Strontium. & 108 \\
\hline Potassium .... & 234 & & \\
\hline
\end{tabular}
volume, which remains the same in all their salts; we will give these atomic volumes in the following table:-

He determines these numbers in the following manner:Suppose $\mathbf{M}+\mathbf{R}$ to be a compound of a heavy metal, $m+\mathbf{R}$ the analogous compound of a light one. Suppose $A$ to be the known atomic volume of $\mathrm{M}+\mathrm{R}$ and $a$ that of $m+\mathrm{R}, \mathrm{B}$ the primitive atomic volume of $\mathrm{M}$, and $b$ of $m$.

Then, atomic volume of $M+R=A$

Prim. atom. volume of $\mathrm{M}=\mathrm{B}$

$$
\overline{\mathbf{A}-\overline{\mathbf{B}}=x},
$$

the atomic volume with which $R$ is contained in the compound. It is assumed that $R$ retains its value in $M+R$; and therefore

$$
\text { Atomic volume of } m+\mathrm{R}=a
$$

therefore peculiar atomic volume of $\frac{\mathrm{R}=x}{m=a-x}$, which are both known. 
on the Specific Weight of Chemical Componnds. 181

For the carbonates the fullowing rule may be given. To the prinitive atomic volumes of the heavy metals, or the peculiar ones of the light metals, the number 151 must be added, which is the assumed atomic volume of $\mathrm{C} \mathrm{O}^{3}$. In this manner the following atomic volumes and densities of the carbonates are obtained:-

\begin{tabular}{|c|c|c|c|c|c|c|c|}
\hline Salts. & $\begin{array}{l}\text { Atom. } \\
\text { Vol. }\end{array}$ & $\begin{array}{l}\text { Calcu. } \\
\text { Sp.Gr. }\end{array}$ & $\begin{array}{l}\text { Obser. } \\
\text { Sp.Gr. }\end{array}$ & Salts. & $\begin{array}{l}\text { Atom. } \\
\text { Vol. }\end{array}$ & $\begin{array}{l}\text { Calcu. } \\
\text { Sp.Gr. }\end{array}$ & $\begin{array}{l}\text { Obser. } \\
\text { Sp.Gr. }\end{array}$ \\
\hline $\mathrm{Pb}+\mathrm{CO}^{3}$ & 265 & $6 \cdot 30$ & $6 \cdot 43$ & $\mathrm{Ba} \mathrm{C} \mathrm{O}^{3}$ & 294 & $4 \cdot 19$ & $4 \cdot 24$ \\
\hline $\mathrm{Cd}+\mathrm{CO}^{3}$. & 932 & $4 \cdot 63$ & $4 \cdot 49$ & $\mathrm{CaC} \mathrm{O}^{3}$ & 211 & 3.00 & 3.00 \\
\hline $\mathrm{Fe}+\mathrm{CO}^{3}$ & 195 & $3 \cdot 67$ & 3.83 & $\mathrm{KCO}^{3}$ & 385 & $2 \cdot 25$ & $2 \cdot 26$ \\
\hline $\mathrm{Mn}+\mathrm{CO}^{3} .$. & 195 & $3 \cdot 70$ & 3.59 & $\mathrm{MgC} \mathrm{O}^{3}$ & 191 & $2 \cdot 80$ & $2 \cdot 98$ \\
\hline $\mathrm{Ag}+\mathrm{CO}^{3}$ & 281 & $6 \cdot 15$ & $6 \cdot 08$ & $\mathrm{NaCO}^{3} \ldots$ & 981 & $2 \cdot 37$ & $2 \cdot 47$ \\
\hline $\mathrm{Zn}+\mathrm{CO}^{3}$ & 209 & $3 \cdot 73$ & $4 \cdot 44$ & $\mathrm{SrC} \mathrm{O}^{3}$ & 259 & $3 \cdot 56$ & $3 \cdot 60$ \\
\hline
\end{tabular}

And for the double salts,

$$
\begin{array}{r}
\text { Bitterspar }\left\{\begin{array}{l}
\mathrm{Mg} \mathrm{CO}^{3} \\
\mathrm{CaC} \mathrm{O}^{3}
\end{array}\right\} 402-2 \cdot 90-2 \cdot 88 \\
\mathrm{Mg} \text { esitin }\left\{\begin{array}{l}
\mathrm{Mg} \mathrm{O} \mathrm{C} \mathrm{O}^{3} \\
\mathrm{Fe} \mathrm{CO}
\end{array}\right\} 386-3.24-3.35 .
\end{array}
$$

All these agree very well, except the zinc salt.

In the nitrates the atomic volume of $\mathrm{N}^{2} \mathrm{O}^{6}$ is assumed to be $=358$.

\begin{tabular}{|l|l|l|l|}
\hline $\mathrm{Pb} \mathrm{N} \mathrm{N}^{6} \ldots$. & 472 & $4 \cdot 40$ & $4 \cdot 40$ \\
$\mathrm{Ag} \mathrm{N} \mathrm{O}^{6} \mathrm{O}^{6} \ldots$ & 488 & $4 \cdot 36$ & $4 \cdot 36$ \\
$\mathrm{Am} \mathrm{N}^{2} \mathrm{O}^{6} \ldots$ & 576 & $1 \cdot 74$ & $1 \cdot 74$ \\
$\mathrm{Ba} \mathrm{N}^{2} \mathrm{O}^{6} \ldots$ & 501 & $3 \cdot 20$ & $3 \cdot 19$ \\
$\mathrm{~K} \mathrm{~N}^{2} \mathrm{O}^{6} \ldots \ldots$ & 592 & $2 \cdot 14$ & $2 \cdot 10$ \\
$\mathrm{Na} \mathrm{N}^{2} \mathrm{O}^{6} \ldots$. & 488 & $2 \cdot 19$ & $2 \cdot 19$ \\
$\mathrm{Sr} \mathrm{N} \mathrm{N}^{2} \mathrm{O}^{6} \ldots$ & 466 & $2 \cdot 84$ & $2 \cdot 89$ \\
\hline
\end{tabular}

In several of the sulphates the atomic volume of $\mathrm{SO}^{4}$ nay be assumed to be 236. According to this the following salts

\begin{tabular}{|c|c|c|c|}
\hline $\mathrm{CuSO}$ & 280 & $3 \cdot 56$ & 3.57 \\
\hline $\mathrm{Ag} \mathrm{SO} \mathrm{O}^{4}$ & 366 & $5 \cdot 34$ & $5 \cdot 34$ \\
\hline $\mathrm{ZnSO}$ & 294 & $3 \cdot 42$ & $3 \cdot 40$ \\
\hline $\mathrm{Ca} \mathrm{SO}^{4}$ & 296 & $2 \cdot 90$ & 2.93 \\
\hline $\mathrm{MgSO}^{4}$ & 276 & $2 \cdot 75$ & $\stackrel{2 \cdot 61}{1}$ \\
\hline $\mathrm{NaSO}^{4}$ & 366 & $2 \cdot 44$ & $2 \cdot 46$ \\
\hline
\end{tabular}
were calculated :-

But the assumption of 236 as the atomic volume of $\mathrm{S} \mathrm{O}^{4}$ does not hold good in some of the other sulphates, so that we are obliged to assume that there are two groups of sulphates, in one of which $\mathrm{S} \mathrm{O}^{4}$ has the atomic volume 236 , and in the other 186. According to this latter number the following salts have been calculated :- 


\begin{tabular}{|ll|l|l|l|}
\hline $\mathrm{Pb} \mathrm{S} \mathrm{O}^{4}$ & $\ldots$ & 300 & $6 \cdot 32$ & $6 \cdot 30$ \\
$\mathrm{Ba} \mathrm{S} \mathrm{O}^{4}$ & $\ldots$ & 329 & $4 \cdot 43$ & $4 \cdot 45$ \\
$\mathrm{~K} \mathrm{~S} \mathrm{O}^{4}$ & $\ldots$ & 420 & $2 \cdot 60$ & $2 \cdot 62$ \\
$\mathrm{Sr} \mathrm{S} \mathrm{O} \mathrm{O}^{4}$ & $\ldots$ & 294 & $3 \cdot 90$ & $3 \cdot 95$ \\
\hline
\end{tabular}

In the chromates we may assume $\mathrm{Cr}^{4}=228$. In the wolframates $\quad . . \quad \ldots \quad \mathrm{WO}^{4}=244$.

\begin{tabular}{|c|c|c|c|}
\hline $\mathrm{PbCr} \mathrm{O}^{4} \ldots$ & 342 & 5.98 & $5 \cdot 95$ \\
\hline $\mathrm{K} \mathrm{CrO} \mathrm{O}^{4}$ & 462 & $2 \cdot 69$ & $2 \cdot 64$ \\
\hline $\mathrm{Pb} \mathrm{W} \mathrm{O}^{4} \ldots$ & 358 & $8 \cdot 04$ & 8.00 \\
\hline $\mathrm{Fe} \mathrm{WO}^{4} \ldots$ & 288 & $6 \cdot 67$ & $7 \cdot 10$ \\
\hline $\mathrm{Ca}^{\mathrm{W}} \mathrm{O}^{4}$ & 304 & 6.05 & $6 \cdot 04$ \\
\hline
\end{tabular}

We must assume that there are two groups of chlorides, in one of which the atomic volume of $\mathrm{Cl}^{2}=196$, and in the other 245 .

\begin{tabular}{|c|c|c|c|c|c|c|c|}
\hline \multicolumn{4}{|c|}{ First Group. } & \multicolumn{4}{|c|}{ Second Group. } \\
\hline $\begin{array}{l}\mathrm{Pb} \mathrm{Cl}^{2} \ldots \ldots \\
\mathrm{Ag} \mathrm{Cl} \mathrm{Cl}^{2} \ldots \\
\mathrm{Ba} \mathrm{Cl^{2 }} \ldots \\
\mathrm{Na} \mathrm{Cl}^{2} \ldots\end{array}$ & $\begin{array}{l}310 \\
326 \\
339 \\
326\end{array}$ & $\begin{array}{l}5 \cdot 60 \\
5 \cdot 50 \\
3 \cdot 83 \\
2 \cdot 25\end{array}$ & $\begin{array}{l}5 \cdot 68 \\
5 \cdot 50 \\
3 \cdot 86 \\
2 \cdot 26\end{array}$ & $\begin{array}{l}\mathrm{Am} \mathrm{Cl}^{2} \ldots \ldots \\
\mathrm{Ca} \mathrm{Cl}^{2} \ldots \\
\mathrm{K} \mathrm{Cl}^{2} \ldots \\
\mathrm{Cu} \mathrm{Cl}^{2} \ldots \\
\mathrm{Hg}^{2} \mathrm{Cl}^{2} \ldots \\
\mathrm{Hg} \mathrm{Cl}^{2} \ldots \\
\mathrm{Sr} \mathrm{Cl}^{2} \ldots\end{array}$ & $\begin{array}{l}463 \\
305 \\
479 \\
333 \\
431 \\
338 \\
353\end{array}$ & $\begin{array}{l}1 \cdot 44 \\
2 \cdot 29 \\
1 \cdot 94 \\
3 \cdot 70 \\
6 \cdot 90 \\
5 \cdot 05 \\
2 \cdot 80\end{array}$ & $\begin{array}{l}1 \cdot 45 \\
227 \\
1 \cdot 94 \\
3 \cdot 68 \\
6 \cdot 99 \\
5 \cdot 14 \\
2 \cdot 80\end{array}$ \\
\hline
\end{tabular}

Neither of the above assumed numbers will explain the specific gravity of bichloride of tin ; it seems, however, unnecessary to assume another value for the sake of only one substance.

The density of several iodides may be approximately explained by assuming the atomic volume of iodine $=361$. In the potassium and silver-salts it is probably 463 .

The atomic volume of bromine in the salts of lead and silver is $=233$; in that of mercury $=290$; and in that of potassium $=375$. These assumptions must be confirmed by more observations. Dr. Kopp then proceeds to a criticism of Schröder's work: he compares the results therein obtained with those given above : he shows that Schröder has made a great many assumptions to explain but few facts, and has not mentioned those salts which do not agree with his theoretical formulæ, and he therefore considers his own theory as the simpler.

'The density of many oxides of the heavy metals may be explained by assuming the atomic volume of oxygen to be $=32$. 
on the Specific Weight of Chemical Compounds.

\begin{tabular}{|c|c|c|c|}
\hline Oxides. & $\begin{array}{c}\text { Calculated atomic } \\
\text { volume. }\end{array}$ & $\int_{\text {Calculated atomic }}^{\text {weight. }}$ & $\begin{array}{c}\text { Observed atomic } \\
\text { weight. }\end{array}$ \\
\hline $\mathrm{PbO}$ & 146 & $9 \cdot 55$ & $9 \cdot 50$ \\
\hline $\mathrm{Cd} \mathrm{O} \ldots . .$. & 113 & $7 \cdot 05$ & 6995 \\
\hline $\mathrm{Cu} \mathrm{O} \ldots \ldots \ldots \ldots \ldots$ & 76 & $6 \cdot 53$ & 6.43 \\
\hline MnO.. & 76 & $5 \cdot 87$ & $4: 73$ \\
\hline $\mathrm{HgO} .$. & 125 & $10 \cdot 9$ & $11 \cdot 00$ \\
\hline $\operatorname{Zn} 0$. & 90 & $5 \cdot 48$ & $5 \cdot 43$ \\
\hline Sno .. & 133 & $6 \cdot 28$ & $6 \cdot 67$ \\
\hline $\mathrm{MoO}^{2}$. & 133 & $6 \cdot 01$ & $5 \cdot 67$ \\
\hline $\mathrm{TiO}^{2}$ & 121 & $4 \cdot 16$ & $4 \cdot 18$ \\
\hline $\mathrm{Pb} \mathrm{O}^{2} .$. & 178 & $8 \cdot 40$ & 8.90 \\
\hline$S b^{2} O^{3}$. & 336 & $5 \cdot 69$ & $5 \cdot 78$ \\
\hline $\mathrm{Pb}^{2} \mathrm{O}^{3} \ldots$ & 324 & 8.91 & 8.94 \\
\hline $\mathrm{Fe}^{2} \mathrm{O}^{3} \ldots \ldots \ldots \ldots \ldots$ & 184 & $5 \cdot 31$ & $5 \cdot 25$ \\
\hline $\mathrm{Co}^{2} \mathrm{O}^{3}$ & 184 & $5 \cdot 64$ & $5 \cdot 60$ \\
\hline Ilmenite 7 & & & \\
\hline $\left.\left.\begin{array}{l}\mathrm{Fe} \\
\mathrm{Ti}\end{array}\right\} \mathrm{O}^{3}\right\} \ldots \ldots$ & 197 & $4 \cdot 78$ & $4 \cdot 78$ \\
\hline $\mathrm{Bi}^{2} \mathrm{O}^{3} \ldots \ldots \ldots \ldots \ldots$ & 366 & $8 \cdot 09$ & $8 \cdot 17$ \\
\hline
\end{tabular}

Some few of these oxides do not agree, viz. $\mathrm{Mn} \mathrm{O}, \mathrm{Sn} \mathrm{O}$, $\mathrm{Mo} \mathrm{O}^{2}$, and $\mathrm{Pb} \mathrm{O}^{2}$. For some oxides the atomic volume must be assumed $=16$, for others $=64$.

\begin{tabular}{|c|c|c|c|}
\hline Oxides. & $\begin{array}{c}\text { Calculated atomic } \\
\text { volume. }\end{array}$ & $\begin{array}{c}\text { Calculated specific } \\
\text { weight. }\end{array}$ & $\begin{array}{c}\text { Observed specific } \\
\text { weight. }\end{array}$ \\
\hline $\begin{array}{l}\mathrm{Sb} \mathrm{O}^{2} \\
\mathrm{Sn} \mathrm{O}^{2} \ldots \ldots \ldots \ldots \ldots \ldots \ldots \ldots \\
\mathrm{Cr}^{2} \mathrm{O}^{3} \ldots \ldots \ldots \ldots \ldots \ldots \ldots \ldots \ldots \ldots \ldots \ldots\end{array}$ & $\begin{array}{l}154 \\
133 \\
186\end{array}$ & $\begin{array}{l}6 \cdot 53 \\
7 \cdot 03 \\
5 \cdot 39\end{array}$ & $\begin{array}{l}6 \cdot 53 \\
6 \cdot 96 \\
5 \cdot 21\end{array}$ \\
\hline \multicolumn{4}{|c|}{ Atomic volume $=64$} \\
\hline $\begin{array}{l}\mathrm{Cu}^{2} \mathrm{O} \ldots \ldots \ldots \ldots \ldots . . \\
\mathrm{Hg}^{2} \mathrm{O} \ldots \ldots \ldots \ldots \ldots \ldots \\
\mathrm{Ag} \mathrm{O} \ldots \ldots \ldots \ldots \ldots \ldots \\
\mathrm{MoO}^{3} \ldots \ldots \ldots \ldots \ldots \ldots . . \\
\mathrm{W} \mathrm{O}^{3} \ldots \ldots \ldots \ldots \ldots \ldots\end{array}$ & $\begin{array}{l}152 \\
250 \\
194 \\
261 \\
261\end{array}$ & $\begin{array}{c}5 \cdot 87 \\
10 \cdot 5 \\
7 \cdot 48 \\
3 \cdot 44 \\
5 \cdot 68\end{array}$ & $\begin{array}{r}5 \cdot 75 \\
10 \cdot 69 \\
7 \cdot 25 \\
3 \cdot 46 \\
5 \cdot 27\end{array}$ \\
\hline
\end{tabular}

Dr. Kopp then shows the untenability of Schröder's theory with respect to the oxides, inasmuch as he has made an assumption for almost every fact to be explained, and a theory which requires as many or more assumptions than there are facts to be explained is quite useless.

The statements, with regard to the densities of the sulphurets, are very insecure and variable, on account of the great difficulty in obtaining them in a sufficiently pure state. The number of assumptions required is therefore necessarily increased. 
184 Mr. H. Croft's Abstract of Dr. H. Kopp's Researches

\begin{tabular}{|c|c|c|c|c|}
\hline \multicolumn{5}{|c|}{ Atomic volume of $S=53$. } \\
\hline $\begin{array}{l}\text { Sulphuret of nickel ... } \\
\text { Iron pyrites } \quad \ldots \ldots \ldots \ldots . .\end{array}$ & $\begin{array}{l}\mathrm{NiS} \\
\mathrm{Fe} \mathrm{S}^{2}\end{array}$ & $\begin{array}{r}97 \\
150\end{array}$ & $\begin{array}{l}5 \cdot 86 \\
4 \cdot 94\end{array}$ & $\begin{array}{l}5 \cdot 76 \\
4 \cdot 90\end{array}$ \\
\hline \multicolumn{5}{|c|}{ Atomic volume $=78$. } \\
\hline 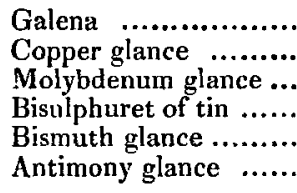 & $\begin{array}{l}\mathrm{PbS} \\
\mathrm{Cu}^{2} \mathrm{~S} \\
\mathrm{Mo}^{2} \\
\mathrm{Sn}^{2} \\
\mathrm{Bi}^{2} \mathrm{~S}^{3} \\
\mathrm{Sb}^{2} \mathrm{~S}^{3}\end{array}$ & $\begin{array}{l}192 \\
166 \\
225 \\
257 \\
504 \\
474\end{array}$ & $\begin{array}{l}7 \cdot 78 \\
5 \cdot 97 \\
4 \cdot 45 \\
4 \cdot 43 \\
6 \cdot 47 \\
4 \cdot 67\end{array}$ & $\begin{array}{l}7 \cdot 76 \\
5 \cdot 74 \\
4 \cdot 44 \\
4 \cdot 42 \\
6 \cdot 40 \\
4 \cdot 63\end{array}$ \\
\hline \multicolumn{5}{|c|}{ Atomic volume $=94$} \\
\hline 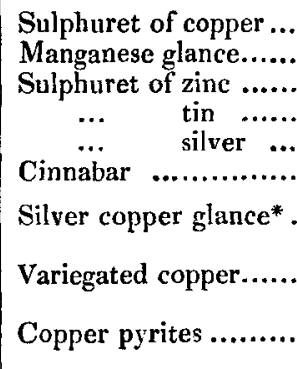 & 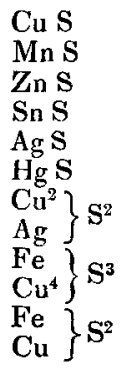 & $\begin{array}{l}138 \\
138 \\
152 \\
195 \\
224 \\
187 \\
406 \\
\\
502 \\
\\
276\end{array}$ & $\begin{array}{l}4 \cdot 33 \\
3 \cdot 96 \\
3 \cdot 91 \\
4 \cdot 80 \\
6 \cdot 93 \\
7 \cdot 84 \\
6 \cdot 26 \\
\\
5 \cdot 03\end{array}$ & $\begin{array}{l}4 \cdot 16 \\
3 \cdot 95 \\
3 \cdot 92 \\
4 \cdot 85 \\
6 \cdot 9 \\
8 \cdot 0 \\
6 \cdot 26 \\
\\
5 \cdot 00 \\
4 \cdot 16\end{array}$ \\
\hline
\end{tabular}

In this table might also be placed some of the more complex sulphurets, whose calculated specific gravities agree very well with those observed.

For the sulphurets of cadmium and platinum, it appears necessary to adopt 110 as the atomic volume of sulphur.

Arsenic is much more closely allied to the metalloids than to the metals, and it seems that in its acids and sulphurets it has the atomic volume $=119$, and not its primitive one; in its compounds with metals and their sulphurets, it seems to require the numbers 74 .

In water and in peroxide of hydrogen, the hydrogen seems to possess the atomic volume 80 , and oxygen 32 , which it has in most metallic oxides.

Dr. Kopp then proceeds to a comparison of the relative merits of the oxyacid and hydracid theories of the constitution of salts, as far, at least, as regards their densities. To enter fully into the reasonings adduced in favour of the hydracid theory would lead us beyond the limits of this abstract: he finds that if the oxyacid theory were retained, a greater num-

* Isometric copper glance.-Mols. 
ber of assumptions would be necessary in the formulæ for the densities of salts than if we adopted the hydracid theory, as the improbability of a theory increases with the number of assumptions which it is obliged to make, and as that theory is the most probable which makes fewest assumptions, Dr. Kopp decides in favour of that of the hydracids. In a future communication we may perhaps enter more fully into this subject.

The densities of several hydrated oxides may be calculated if we assume the water to have the atomic volume 78 , and the oxide to retain its primitive volume.

\begin{tabular}{|c|c|c|c|c|}
\hline 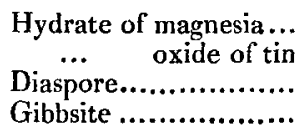 & $\begin{array}{l}\mathrm{MgO}+\mathrm{H}^{2} \mathrm{O} \\
\mathrm{SnO}+\mathrm{H}^{2} \mathrm{O} \\
\mathrm{Al}^{2} \mathrm{O}^{3}+\mathrm{H}^{2} \mathrm{O} \\
\mathrm{Al}^{2} \mathrm{O}^{3}+3 \mathrm{H}^{2} \mathrm{O}\end{array}$ & $\begin{array}{l}159 \\
211 \\
242 \\
398\end{array}$ & $\begin{array}{l}2 \cdot 33 \\
4 \cdot 96 \\
3 \cdot 11 \\
2 \cdot 46\end{array}$ & $\begin{array}{l}2 \cdot 35 \\
4 \cdot 93 \\
3 \cdot 36 \\
2 \cdot 40\end{array}$ \\
\hline
\end{tabular}

In some hydrates of salts the volume of water must be 84 .

\begin{tabular}{|c|c|c|c|c|}
\hline Chloride of barium & $\mathrm{BaCl}+2 \cdot \mathrm{H}^{2} \mathrm{O}$ & 507 & 3.00 & $3 \cdot 05$ \\
\hline Sulphate of lime & $2 \mathrm{Ca} \mathrm{SO}^{4}+\mathrm{H}^{2} \mathrm{O}$ & 676 & $2 \cdot 70$ & $2 \cdot 76$ \\
\hline Gypsum & $\mathrm{CaSO} \mathrm{O}^{4}+2 \mathrm{H}^{2} \mathrm{O}$ & 464 & $2 \cdot 33$ & $2 \cdot 33$ \\
\hline Sulphate of copper & $\mathrm{CuSO} \mathrm{O}^{4}+5 \mathrm{H}^{2} \mathrm{O}$ & 700 & $2 \cdot 24$ & $2 \cdot 23$ \\
\hline mangane & $\mathrm{MnSO} \mathrm{S}^{4}+5 \mathrm{H}^{2} \mathrm{O}$ & 700 & $2 \cdot 15$ & $2 \cdot 10$ \\
\hline nickel... & $\mathrm{NiSO}^{4}+7 \mathrm{H}^{2} \mathrm{O}$ & 868 & $2 \cdot 03$ & $2 \cdot 04$ \\
\hline zinc .. & $\mathrm{ZnSO}+7 \mathrm{H}^{2} \mathrm{O}$ & 882 & $2 \cdot 03$ & $2 \cdot 04$ \\
\hline magnesia & . $\mathrm{MgSO} \mathrm{SO}^{4}+7 \mathrm{H}^{2} \mathrm{O}$ & 864 & $1 \cdot 79$ & $1 \cdot 75$ \\
\hline
\end{tabular}

Other salts require the atomic volume 96 .

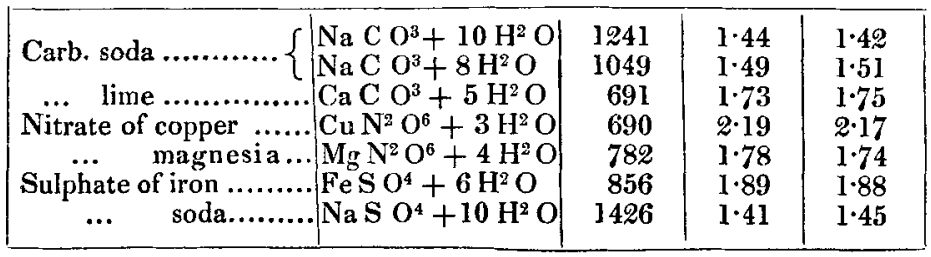

Of the combinations of the metalloids with one another, we nay mention those of chlorine. In this group the atomic volume of chlorine $=298$. The volume of the metalloid comlined with it remains primitive.

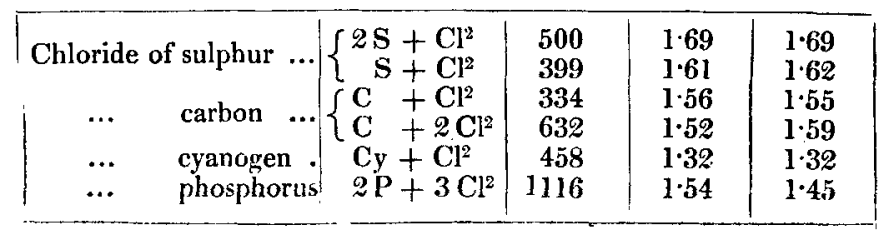


Dr. Kopp then goes on to disprove the assumption of Schröder, viz that the atomic volume with which an element is contained in a compound, bears a simple relation $\left(\frac{1}{2}, \frac{1}{3}-\frac{1}{9}\right.$; $\left.\frac{2}{1}, \frac{2}{3}-\frac{2}{9} ; \frac{8}{1}, \frac{8}{2}, \frac{8}{3}-\frac{8}{9}\right)$ to its primitive atomic volume.

Sesquioxide of iron, sesquioxide of cobalt, ilmenite, and oxide of chromium are all nearly isomorphous. Their atomic volumes are nearly equal.

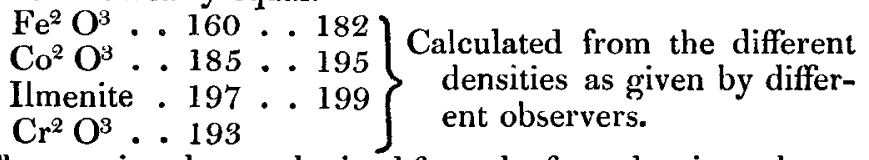

The atomic volumes obtained from the formulæ given above, are-

$\left.\begin{array}{l}\mathrm{Fe}^{2} \mathrm{O}^{3}=184 \\ \mathrm{Co}^{2} \mathrm{O}^{3}=184 \\ \mathrm{Ilmenite}^{3}=197 \\ \mathrm{Cr}^{2} \mathrm{O}^{3}=186\end{array}\right\} \begin{gathered}\text { which agree tolerably well with the } \\ \text { preceding values. }\end{gathered}$

According to the atomic theory, in regard to the composition in equivalents, the four above-mentioned oxides are perfectly similar in their composition; but according to the theory of atomic volumes, as regards the manner in which the atomic volumes of the compounds are composed, there is a total dissimilarity.

In the oxides of iron and cobalt, and in ilmenite, the atomic volume of oxygen is 32 ; in that of chromium it is 16 . Oxide of iron and oxide of chromium are isomorphous; they have however not the same constitution in atomic volumes. The sums of the atomic volumes of the elements in both compounds are equal; the atomic volume of oxide of iron is equal to that of oxide of chromium. In the oxide of iron each atom of iron occupies a space $=44$; each atom of oxygen a space $=32$; in oxide of chromium an atom of metal occupies a space $=69$, and an atom of oxygen a space $=16$. How can this be explained if these compounds are formed by simple juxtaposition of their elements? The same form can never be obtained by laying together two balls, each of which contains 44 cubic unities (inches, feet, \&c.), and three balls of 32 cubic unities contents, as by putting together two balls, containing eacl 69 cubic unities, with three balls of 16 cubic unities, althougi $2 \cdot 44+3 \cdot 32$ is nearly equal to $2 \cdot 69+3 \cdot 16$. Other similir cases might be adduced, and they are altogether contrary $o$ the idea of juxtaposition. Dr. Kopp is almost inclined to assume a penetrability of matter.

It appears that there are cases in which an element, con- 
bining with another in several proportions, does not always retain the same atomic volume, although these cases appear to be of less frequent occurrence than those in which it always retains one and the same atomic volume.

The above is a short abstract of Dr. Kopp's most important researches on the specific weight of chemical compounds; at the same time he published another work on the specific gravities of arbitrary mixtures, in which there are some important considerations with regard to the hydracid theory. Should the above abstract meet with the favour of British chemists, I may perhaps be induced to attempt something similar with the last-mentioned work .

January 11 th, 1842.

35 Upper Gower Street, London.

Henky Croft.

XXVIII. On a great Regularity in the Physical Properties of analogous Organic Compounds. By Dr. Hermann Kopp, Lecturer at the University of Giessen*.

T $\mathrm{N}$ a recent publication on the Specific Weights of Chemical 1 Compounds $t$, I endeavoured to show how the atomic volumes of analogous groups of such combinations might be very simply explained by means of certain general admissions, and how the specific weight of any compound belonging to such a group might be determined $\dot{a}$ priori with considerable accuracy. This work was confined to inorganic compounds: I have since then extended my researches to the organic combinations, and have likewise arrived at very simple results.

In organic chemistry there are proportionally more liquid compounds than in the inorganic, and the existence of dimorphism, which frequently renders the discovery of the laws for the specific weight difficult in this latter branch, is of rarer. occurrence. The determinations of the densities of fluids are in general easier, and the statements respecting them more accurate than is the case with solid bodies. On the other hand, fluids have a greater expansibility by heat than solids, and as long as it remains unascertained at what temperature a comparison of the specific volumes of various bodies can properly be made, this stronger expansibility, which varies in different compounds, appears to lay great difficulties in the way of our arriving at correct results from a comparison of specific volumes. I have not hitherto been able to devote any special attention to this subject, on account of the several

* Communicated by the Author.

+ Vide preceding abstract by Mr. H. Croft. 